\title{
Epilogue:
}

\section{Translating Experience into Biomedical \\ Assemblages. Observations on European \\ Forms of (Imagined) Participatory Agency \\ in Healthcare}

\author{
STEFAN BECK
}

The following pages cannot rightfully claim to be an epi-logue rather, they are attempting something akin to an aside-logue to the issues analysed in this book. Instead of focusing on practices of health promotion per se, the article sets out to begin thinking about what could be called the "reflexive consequences" of a promotional health care approach; it aims at a partial view of the reception-end of health care promotion. What do those people who are shealth promoted think and do? How do they perceive medicine, medical experts and prevention programmes? What do they expect from the medical system and what do they attempt to change? I will neither attempt to provide a comparative perspective on modes of participation of patients in diverse European medical systems, nor will I systematically dissect the complex relations of biomedical assemblages, biomedical citizenships, participatory regimes, new forms of subjectification, medical governance, and antagonistic as well as cooperative modes of knowledge production in the transaction zone between medical and patient expertise; these topics were taken 
up by the articles in this book. Instead, I will suggest some hypotheses, providing some rather pointillistic evidence and food for thought. I will use empirical findings of a multisited research project funded by the European Union ${ }^{1}$ to look into how patients and "concerned people " perceive biomedicine and the ethical challenges that come with new regimes of medical intervention.

Specifically, I will argue that the concept of health promotion, as it is commonly applied in public health programmes, is hampered by an unidirectional concept of in-formation: an understanding where abstract medical knowledge is set in motion by experts to transform the lives and practices of nonexperts that are considered to be "not in the know «. As a consequence, most health interventions do not actively attempt to systematically integrate experiences of patients and nonexperts into their programmes - resulting in a systematic unreflexivity. However, patients and the »targets " of health services can try to mobilise their experiences in an attempt to translate their knowledge back into biomedical assemblages, thereby making healthcare more reflexive. The conclusion of the following argument is simple: to make preventive health policies more reflexive, a relational concept is needed that focuses on a $b i$ directional translation of experience and knowledge between health experts and patients/concerned people.

My multi-layered hypothesis will consist firstly of a critique of the critique of medicalisation; secondly of the proposal that we are witnessing a de-socialisation of medicine due to the intensification of collaborations with other life-sciences, and thirdly the suggestion that attempts to re-socialise medicine via novel routes are well under way, for example by subjecting medicine to trials of accountability or economic interests. I will present some empirical material of how the respondents of the aforementioned research project confront the boundaries of medicine, and finally I will portray some exemplary zones of

1 The project »Challenges of Biomedicine« (EU Project no. SAS6CT-2003-510238), coordinated by Ulrike Felt in Vienna (Dept. of Social Studies of Science); see the website for participating researchers, institutions, research design and a brief summary of main findings: http://www.univie.ac.at/virusss/cobpublication. 
engagement where patients are trying to translate their experiences into the medical assemblage.

\section{From medicalisation to biomedicalisation}

The dominant critique of western medicine is the critique of medicalisation, a word used to denote - in the words of sociologist Irving Zola - that in modernity »more and more of everyday life has come under medical dominion, influence and supervision« (Zola 1983: 295). However, this critique hinders a sufficiently complex analysis of recent developments in the production and application of medical knowledge. To its followers, medicalisation signifies a process in which a medical frame or definition is applied to understand or manage a problem. Well-known examples include the founding of medical institutions such as birth-houses in which poor women had to give birth under medically controlled conditions, or the recent emergence of new syndromes like Attention Deficit/Hyperactivity Disorder that define a complex behavioural phenomenon as caused by neurological states. Specifically, medicalisation describes a process of social control in which phenomena, formerly understood to be non-medical or even non-problematic, »become defined and treated as medical problems, usually in terms of illnesses or disorders « (Conrad 1992: 209). ${ }^{2}$ More often than not, medicalisation is understood to be a linear process unfolding in modernity parallel and connected to to secularisation.

However, the theorem of medicalisation, while affording a powerful critique of the medical system, creates considerable blind spots. The most prominent of these allows changes in the composition of medical knowledges and the logics of medical practices to be played down in a perspective that privileges the analysis of unchanging and stable power asymmetries between science and everyday life-worlds. In particular, the ongoing

2 Early studies in medicalisation processes in the late 1960s and early 1970s took their inspiration in part from Talcott Parsons (1951), who was "probably the first to conceptualize medicine as an institution of social control« (Conrad 1992: 210). 
biomedicalization (Clarke, Shim et al. 2003) of medical knowledges and practices themselves, including the complex effects of the converging knowledges of molecular biology, genetics, biochemics, information sciences and mathematics, has revolutionised the epistemic basis of medicine. In addition to this, the »institutional sites of health-care knowledge production, distribution, and information management « (ibid: 162) are being remade, and a complex, internationally networked system is emerging that consists of hospitals, clinical research, research group practices, pharmaceutical research and development, healthcare management organisations, bioscientific and medical technologies, and supplies industries. One would expect that any analysis of this complex network would take into consideration power asymmetries that go far beyond a simple science/life-world divide as is suggested by the trope of medicalisation. Instead of taking the linear process of medicine expanding to other domains for granted, one should - following Donna Haraway and others - instead try to achieve a better understanding of the potentiality and dynamics created by the inherent hybridity of the medical system and its multiple transaction zones (see Beck and Niewöhner 2006) that are the outcome of multiple resistances - be they material, political, economical or social.

Such a perspective would also shed some light on the effects of the pervasive neo-liberal reforms of medical systems in industrialised societies, which have since the 1980s reconfigured medicine beyond recognition. Both the substance and form of doing medicine have been thoroughly transformed in recent years. The interfaces between medicine and society have been reassembled, as were the forms and the modes of domination, influence and supervision that medicine could sustain or aspire to command. In consequence, new social transaction zones between public/private, government/corporation; expert/lay, patient/consumer; physician/insurer; and university/industry/state, as well as new, related ways to »know and take care of thyself « have come into being. In the words of Adele Clarke and colleagues, historians of medicine: »we see new forms of agency, empowerment, confusion, resistance, responsibility, docility, subjugation, citizenship, subjectivity, and morality" (Clarke, Shim et al. 2003: 185). Indeed, these are "zones of 
awkward engagement « (Tsing 2004: xi) that provide »infinite new sites of negotiation, percolations of power, alleviations as well as instigations of suffering, and the emergence of heretofore subjugated knowledges and new social and cultural forms.«(Clarke, Shim et al. 2003: 185).

\section{The desocialisation of medicine?}

The combined impact of the medicalisation critique from the outside and the growing Verwissenschaftlichung - "scientification « - of medical practices through their intense collaboration with biology and genetics ${ }^{3}$ has led to an increasing disengagement on the part of medical practitioners with the social and cultural issues of illness and individual suffering and, more generally, with the lives of patients in their respective social contexts.

This alienation is of course also due to a growing epistemological, i.e. methodological and theoretical and institutional gap between the new biomedicalised medicine and the social sciences. From its foundation by Émile Durkheim or Max Weber in the early $20^{\text {th }}$ century, sociological theory building has always privileged a resolutely anti-naturalistic explanatory strategy: an understanding of the "social « as the causal order in its own right was a cornerstone in the foundation of the new discipline. The dichotomy suggested by Wilhelm Dilthey (1923) between Erklären und Verstehen - between explaining natural phenomena and understanding social and mental phenomena strengthened this anti-naturalism in the humanities and the social sciences. As the sociologist Ted Benton (2005) argues, this rift only grew in the $20^{\text {th }}$ century as a result of recurrent attempts of biologists to extend the range of their explanatory claims to the social - be it sociobiology or evolutionary psychology. In both cases, the social appeared only as a rather uninteresting epiphenomenon of fascinating biological processes namely of mutation and selection on the genetic level. According to Benton, this powerful - but nonetheless unrefined - re-

3 Clarke et al. (2003) call this process »the technoscientization of biomedicine $\ll$. 
ductionism appalled social scientists and resulted in a systematic avoidance of research into physiological phenomena.

As I see it, we are currently witnessing the outcome of a dual »disengagement«: the new biomedicine is disengaging from the social, the social sciences are disengaging from the natural. Whatever the reasons, the result is, on the one hand, a marked decline in an interest in social causes of medical conditions and physiological effects of particular life-worlds, such as living social inferiority (Charlesworth, Gilfillan et al. 2004). On the other hand, a growing lack of enthusiasm for life-world interventions has developed, a disinclination to guide patients from illnessexperience to restored health. In sharp contrast to this disengagement, good old paternalistic medicine, while at the same time trying to medicalise phenomena had to boldly intervene into the life-worlds of their patients. This necessarily meant that they had to develop a much clearer picture of what it meant to be ill socially and culturally. Consequently, old-fashioned medicine in the traditions of Rudolf Virchow, Louis Pasteur and Robert Koch was highly attentive to environmental effects and lifeworld phenomena that had pathogenic effects or hindered salutogenesis.

But the biomedicalization of medicine led not only to a desocializing of medical practices. The increased intermingling of medical knowledge production with other life-sciences subjected clinical medicine to processes that were more characteristic of the experimental sciences (Gieryn 1999; Stengers and Smith 2000). As Steven Shapin and Simon Schaffer put it: modern scientific knowledge became "a form of knowledge that is the most open in principle [but] has become the most closed in practice (Shapin and Schaffer 1985: 336). The historical closure of scientific epistemic cultures has not only meant the exclusion of charlatans and the untrained public or a defence against normative trespassing from religious and worldly authorities; most of all it has involved the construction of robust objects of inquiry. However, medicine's epistemic object, the body, is peculiar in being an irreducibly dual or ambiguous entity. On the one hand there is the scientific, universal object-body known through the pathological gaze from the outside, but on the other hand there is the embodied subject-body, »the fleshy situatedness of our modes of living " (Mol and Law 2004: 43) that is beyond 
or before language, that is self-aware and socially performed and that accordingly involves completely different modes of knowing, incompatible with objectivist epistemic practices. The classic solution invented by medicine for dealing with this duality - suggested, for example, as early as 1902 by the Polish philosopher of medicine Edmund Biernacki - is a sort of multiple identity. According to this description, two types of medical practices are to be distinguished: (A) the "science of diseases", i.e. physiology and pathology, and (B) the »art of healing ", i.e. therapeutic, highly individualised interventions into self-aware, reflexive bodies, where the patient-doctor interaction becomes central (Biernacki 2000: 49). Mark Sullivan - and with him many medical anthropologists, medical sociologists and a growing number of medical practitioners - argues that this dualism between the object-body known by modern medicine and the self-aware subject-body can be overcome by integrating people's self-awareness back into modern medicine (Sullivan 1986). The utopia here is an integrated, holistic body concept (Harrington 2002).

Transforming modern medicine will not come overnight: as Annemarie Mol and John Law convincingly argue, any attempt to simply add the patient's self-awareness to knowledge resulting from the systematic application of the clinical or epidemiological gaze will be futile. Biomedical epistemic practices prevent the social from entering the house of medical knowledge through the front door. However, the social loiters around at the back door, waiting for unexpected and often nasty appearances - in instances of failed compliance, in psychosomatic disorders, or in the biosocial looping effects described by Ian Hacking and others. In all these cases, the social makes itself "visible « in a mode that medicine is only able to reflect upon as disturbances of established thought-styles, as disruptions of routine medical practices that have to be eliminated. Any truly integrative approach would instead require a thorough re-conceptualisation of the medical object and of medical practices that acknowledges socially embedded bodies. The impressive growth of biomedical knowledge and the success of etiological model-building in recent years do not exactly help to convince medical practitioners or researchers to re-conceptualise their object of study. The price to be paid for 
this negligence will unfortunately be a sustained ignorance of the socio-cultural dimensions of health and disease. The issue at hand, then, is to investigate the mechanisms that could bring social context back to medicine and make embodied selves visible to medical practitioners and researchers.

\section{Re-socialising medicine via accountability trials?}

Although the socio-cultural dimension has been muted, other facets of the "social« are increasingly impacting scientific practices through the side-doors. We find a growing entanglement of industry and state-funded research, especially in the sector of the life sciences. Emblematic for this interpenetration is the 25-million-dollar sponsoring deal that was supposed to give Novartis almost complete control over the Berkeley Biology Department in 2000, or the fact that researchers are switching back and forth between corporate and university labs. Another route of social influence into university research is the reformulation of property rights and their expansion into new phenomena that were not proprietary before, such as »naturally occurring « proteins or gene sequences. This not only introduced market rationality into the context of basic research at universities, but opened up the possibility for mergers between risk-capital and innovative ideas at the bench. As the sociologist of science Peter Weingart (2001) observes, the result is a double dynamics of an "academisation « of industrial research and a growing commercialisation of academic research in the field of the life sciences. Accordingly, it is increasingly difficult to demarcate sites of knowledge production from sites of knowledge application and research decisions from economic decisions - a demarcation that is crucial for the dearly held definition of what "science is and what it is not (Stengers and Smith 2000).

What is of interest to me in the context of this paper is that these phenomena, (A) what I have described as the tendency towards the de-socialisation of medicine, as well as (B) the growing integration of economic rationalities and monetary »interests « into scientific practices, are both perceived to create 
accountability problems from the perspective of health care policies and health care consumers. The notion of accountability includes the application of moral as well as economic reasoning and stands for an arsenal of bureaucratic instruments and institutionalised expectations (Strathern 2000). What makes questions of "accountability « interesting from an anthropological point of view is that they shape subjects and objects in a specific way, and this way applies to all players in the field. For example, by looking at doctor-patient relationships through the lens of accountability, three patterns emerge: the patient in need, the citizen entitled with rights or some sort of amalgamated patient-citizen (see Sang 2004).

\section{From object to subject of care?}

The discussions about the draft for an European Charter of Patients' Rights are an example of where the "social « audibly knocks at the door of medicine, using accountability as the knocker: the charter defines fourteen patients' rights, seeking to "guarantee a >high level of human health protection< [...], to assure the high quality of services provided by the various health services [...] throughout the entire territory of the European Union" (Network 2002). The European draft Charter is based on the French Charter for hospital patients, that states: »Le patient hospitalisé n'est pas seulement un malade. Il est avant tout une personne avec des droits et des devoirs." (Circulaire ministérielle $\mathrm{n}^{\circ}$ 95-22 du 6 mai 1995). The Charter attempts nothing less than to subject biomedicine and health care institutions, be they private or public, clinical work or research, to Article 35 of the Nice Charter of Fundamental Rights, framing medicine as a dependent subsystem of society. This is the antithesis of the self-image of science understood as a truthproducing container shielded from society as described by Shapin and Schaffer. Interestingly enough, Part Three of the draft Charter defines the "rights of active citizenship", which include the right of citizens to perform sauditing and verification activities « in the European health care systems, as well as the right to participate in policy-making in the area of health. In short, the Charter tries to develop a route suitable for making 
parts of the subject-body known to medicine, that is to say: it uses the instruments of accountability trials to translate the patients' points of view, desires and needs into the biomedical assemblage.

The Charter is, however, characterised by a specific ambivalence. Although it explicitly tries to strengthen the role of patient associations in monitoring the performance of health care systems and setting research agendas, the language of individual rights is used throughout the document and the core idea of protecting the autonomy of patients accentuates the concept of the individual as a consumer of health products. Combined with the implementation of bureaucratic instruments of accountability that require well-defined deliverables, a standardisation of health interventions as well as a formalisation of patient-doctor relations might be a rather unintended consequence. The highly standardised »informed consent forms « could serve as a model in this regard. Despite the best intentions, they do not primarily produce informed patients: instead, they mainly serve to protect physicians against redress and litigation. Given these prospects, a recent intervention of the European Ombudsman, political scientist Nikiforos Diamandouros, is relevant. He distinguishes between two models of doctor-patient relationship that are based on two different ideas of "what equality and autonomy should mean" (Diamandouros 2005: 7). Diamandouros calls the first model "consumerist and depicts it as influenced by the American model, which tries to compensate for the inequality of knowledge and expertise of patients and physicians by supplying full information and giving patients unconstrained choice. The alternative model, termed "communicative" and which is his ideal »European model - if I interpret the Ombudsman correctly - does not try to overcome power asymmetries between patient and physician through a flow of medical knowledge. Instead, it uses this asymmetry as a resource by considering the patient as an "autonomous agent making choices about one's own life " who is in need of information, advice and even guidance (Mol 2008).

What is remarkable in the context of my argument is that the communicative model of the doctor-patient relationship which does not presuppose a virtual equality provides a much 
better transaction zone for the exchange of experiential knowledge - be it the patient's or the physician's - than the consumerist model. This product-oriented model claims to secure power-equality through informational transparency, and is therefore restricted to formalised exchanges. It is obvious that these are idealised models; our question was how our respondents in the mentioned research project perceived these issues.

For the moment, let me take up the issue of »interests" again. The aforementioned demarcation between pure, disinterested, truth-producing science on the one hand and the normatively spoilt, interest-driven life-world on the otherhas never been very convincing, either theoretically or empirically. Even in the 1930s, Robert Merton pointed out the intricate interdependence between social institutions in modernity - be it science, the military, economy, or religion - which culminated in the dynamic development of the industrial-military-scientific complex of the 20 th century (Merton 1973). What has to be explained, then, is why the ideal of a disinterested scientific practice is upheld against the overwhelming evidence. Niklas Luhmann suggests that the classic theoretical exclusion of interests from epistemic practices in science established a contrafactual ideal that nevertheless served as an important means of quality control in the production of objective truths. Following this ideal, experimental data and the knowledge created from it are not ascribed to acts - since acts are per definitionem always contaminated by individual interests, motives and emotions. Instead, scientific knowledge is attributed to experience that is conceived of as being independent from individual actors and their specific interests: it is attributed to factors external to the social.

Accordingly, Luhmann suggests that any sociology of knowledge production has to stick to the paradoxical operation of including the acts of exclusion of interests from their field of study into their observations. More precisely, he suggests closely observing how the exclusion and inclusion of interests in systems of knowledge production are "managed « and to what extent the potentially "contaminating « contexts of scientific practice are taken into account (Luhmann 1990). Central for my argument here are two points: firstly, the decisive role experience plays as the foundation for truth claims in science. I 
argue that members of patient associations invoke their experience as sufferers not only to make moral claims but to use it as a powerful mode of claiming the truth. The second point is a mirror image of the first: by criticising the fact that interests foreign to science are gaining importance, patients assess biomedicine in front of the backdrop of the idealised, powerful image of "pure science" in order to de-legitimise new knowledge practices. I will now present a selection of empirical material in which our respondents bring all of these problems into play at once.

\section{Confronting the boundaries of (impure) science}

The following exchange is from a focus group discussion of seven participants »affected « in some way or another by genetic testing, either as patients or as experienced experts. ${ }^{4}$ The interchange develops between a female general practitioner, a male prostate cancer patient, and a male Crohn's disease patient, both of whom are leaders of self-help groups. Referring to her medical training in the early 1990s, the general practitioner asserts:

»back then [the expression] >support group was an insult amongst doctors. And now, if I think about the last months of my residency, when I worked a lot with neurologists [...], they only worked with support groups. They have, that was an extension [i.e.: they used it for their purposes, S. B.].«

The leader of the Prostate Cancer Support Group, however, cautions:

»There are many support groups, and no quality criteria, [there are groups] that are initiated by medical staff, as well as by doctors, [there are groups] that are initiated by pharmaceutical companies...<

The Leader of the Crohn's patient group (cutting in): '...We have also realised that some doctors shamelessly abuse support groups, because

4 This focus group discussion was facilitated in the context of the aforementioned EU project (see footnote 1). 
they find out $[\ldots]$ where there are really good people, dedicated people, they send them all to support groups, because it is too much for them, right.<

The general practitioner: >No, but it is clear, you are the experts. Yes.`

The Crohn's disease patient: `Exactly, and that's exactly what I want to say.<

The general practitioner: ^Now [...] as that we as doctors have finally understood that, that you are the experts, and if we finally [...] want to collaborate with you, then you are surprised (laughing).« (focus group discussion)

The Crohn's disease patient adds what he sees as the prevailing mind-set of many physicians:

"what we as physicians are simply not able to do anymore, we give it to the support group and they should [do it].«(focus group discussion)

In this brief and very cordial exchange, there are a number of topics that recur throughout the empirical material and are of central concern to my hypotheses. First of all, all participants here claim that medical practitioners use patient groups for the delivery of emotional support, psychological stabilisation and individualised or even basic medical information. The reasons are not quite clear, but changing work conditions on the part of physicians as well as a lack of interest and training in sociopsychological issues are clearly alluded to. From the perspective of the leaders of the two patient groups, this constellation is partially experienced as abuse - it is seen as an unfair delegation of responsibilities from experts to volunteers that is clearly overtaxing the strained resources of these insufficiently funded groups. But here as well as in other exchanges the picture created by participants is more complex. Recurrent references are made to "sponsored « support groups that are financially dependent or even founded by pharmaceutical companies, the medical profession or research institutions. The work of these groups is observed with circumspection and even suspicion.

But the three mentioned discussants fully agree that the social unresponsiveness of the medical system (or to be more 
precise: the indifference of physicians) is not easily overcome by the activities of patient groups. Many of our respondents see the reason of this unresponsiveness and the lack of accountability to patients' needs as proof that science is becoming increasingly »impure «, spoiled with interests that are foreign to medicine proper. Perhaps we shouldn't wonder: our respondents are members of liberal societies, predisposed to the view that the public good is maximised by giving the whole range of legitimate individual interests the chance of being pursued. To them, the idea of strengthening patient rights or involving patient groups in the policy process appears to be a clever fix of corporate domination in the medical field.

Quite contrary to the hopes of its proponents, it seems that these voluntary activities may well widen the gap between medicine and the life-world: according to the accounts quoted above, medical practitioners seem only too happy that patient groups shoulder the burdensome work of providing information, integration and political representation to individual sufferers. This should caution against viewing the proliferation of patient groups and the current, widespread demand for participatory policies in the domain of health care and medical research simply as a sign of progress and democratisation. As already argued before, the demand for patient rights is a response to the ongoing biomedicalisation and de-socialisation of health care, but a response that might be likely to paradoxically advance this dynamics.

The second central issue in the exchanges of the focus group discussions is the question of expertise - what it is and who can legitimately claim the status of being an expert. What is probably most striking in going through the material of focus group discussions and interviews is the profound scepticism, the disappointment and to some extent even the animosity that respondents who have experienced genetic testing or organ transplantation articulate when asked about their evaluation of physicians and the performance of the medical system. According to our respondents, there are several major problems that - if the statements are carefully interpreted - are perceived as caused by specific constellations of Erkenntnis und Interesse - of knowledge/cognition and interest. Our respondents perceive a pervasive hybridity of epistemic formations that is not congruent 
with established self-promotions and public expectations of scientific practices as truth-oriented and neutral. At issue here is the interpenetration of economy, politics and science I mentioned earlier. ${ }^{5}$ What we gather from our material is a snapshot of how the debates about science, the popularised findings of science and technology studies and the recent scandals in the field of science have shaped civic perceptions of scientific practice. A short exchange in a French focus group of not affected participants about the potential role of citizens' committees in policy making is representative of this view, which understands science as a form of situated practice:

A middle-aged male artist: $[\ldots]$ governments are subjected to lobbies. Right, well, lobbies are pursuing their interests, and the [...] experts have links because, to be an expert, you have to have been shaped in the mould, by the networks, relationships with labs ... No, personally I can see [...] that [the advice of] citizens' committees [...] would be as valid [...] and in any case more independent than that of experts, or governments, or I don't know. [A small remark by another speaker, then he continues] And [we] could force experts to speak under oath, with checks and a non-commutable sentence if they lied.

A middle aged female teacher: That really shows all the trust we have in our institutions!

The artist again: >Absolutely [laughs]. And in this case, I'm old enough to be able to judge. Don't you agree? « (focus group discussion) ${ }^{6}$

Emerging from this and many similar accounts is a rather balanced picture, far off from the worst expectations of the anticonstructivist defenders of science. Instead, it is quite a sober observation that to be an expert means that one has to be shaped in the mould, that one has to be part of a community of practice that positions every scientist in a social field that conditions his relevancies, perspectives, decisions and actions. The view of our

5 To put it bluntly: If you ever were guessing - according to our material, the constructivists won the science wars of the 1990s in the public vote.

6 This French focus group was facilitated by Anne Masseran and Philippe Chavot in Marseille (see footnote 1). 
discussants is generally constructivist, not in the vulgar "anything goes «-sense but in a partially enlightened sense, fully compatible with their own everyday experiences, that their minds and deeds are shaped by economic, political and cultural conditions. While most of our respondents do not question science per se and hope that they might eventually profit from scientific progress, they do not have faith in the biomedical system that pursues specific paths of progress, trying to maximise profits for its practitioners. Lacking trust in institutions is the trope most often used to discuss this perceived tension between the ideal of science and its institutionalised forms.

The critique of the performance of the biomedical system is grimmer when affected respondents review scientific practices. They assess biomedicine not only as interested practice but quite fundamentally as a specific form of knowledge practice that is only partially fit to do its job. According to the evaluation of our respondents who have had experiences with genetic testing or organ transplantation, there are three problems related to dominant biomedical knowledge practices: (A) respondents provided us with a plethora of anecdotes where insufficient, misleading, or even false information was given to patients. According to these accounts, physicians as the first, crucial point of contact with the biomedical system lack factual knowledge, either because science develops too quickly to keep up-to-date with the latest findings as a professional under the constant pressure of work, or because the problems are too complex to be dealt with by experts that received only a highly specialised training. (B) Most physicians are seen to lack emotional knowledge, so that they are not able or willing to cope with the existential problems of their patients, especially if these are confronted with the diagnosis of a potentially deadly or chronic disease. Finally, (C) biomedical experts are judged to lack experiential knowledge of what it means to cope with a severe illness that demands therapeutic interventions and confronts issues of stigmatisation on a daily basis.

While those of our respondents who had no specific prior experiences with genetic testing or organ donation mostly stated that they more or less trusted the medical system, those who did have prior experiences as patients often expressed ambivalent feelings about the reliability of the medical system and 
its practitioners. They have no alternative to trust while they have many reasons to be sceptical. The following quote is from a female respondent from Germany, aged 32, who is suffering from an inherited cardiomyopathy and is on the waiting list for a heart transplantation. Note that she uses the impersonal German »man« (one) to distance herself from her mixed feelings:

"In any case, I want to have confidence in the domain of medicine, in all the little steps that happen, but one has somehow lost it. One gets more careful, I have to say. Beginning with the little things, with a stay at the hospital. If you are in several hospitals, you already see differences: how it works here, how it works there, there I'm much, much better, there they gave me this and that pill, here they actually talked to me and there nobody talked to me at all. Well, all this is varies a lot. Or this feeling at the ... cardiologist's I wait for 3 hours, they give me an appointment at 3 p.m. and it's my turn at 7 p.m. There I say to myself: hello, I'm not well, can I be the next one please? And then it's the private patients' turn before me, of course, I'm just - let me have it this way - an unglamorous health plan patient. You lose confidence at some point. [...] that's what I think. It's just - well, real trust - I don't know.« (patient interview $)^{7}$

In analysing the issues of trust and expertise that are recurrent in our interviews and focus group discussions, some differentiations made by the sociologist Anthony Giddens might be helpful. For Giddens, modernity is generally characterised by all-encompassing abstract systems. These abstract systems emerge when social relations are moved from direct, local interactions of co-present actors to increasingly indirect, distanced, abstract interactions. Giddens terms this process the disembedding of social relations. One of the most powerful disembedding mechanisms in the development of modern institutions is the establishment of expert systems. These expert systems, according to Giddens, arrange technical accomplishments and professional expertise that in turn organise the »material and social environments in which we live today" (Giddens, Consequences, 27). And again Giddens:

7 This interview was conducted by Katrin Amelang in the context of the EU project (see footnote 1). 
»Most laypersons consult 'professionals< - lawyers, architects, doctors, and so forth - only in a periodic or irregular fashion. But the systems in which the knowledge of experts is integrated influence many aspects of what we do in a continuous way. Simply by sitting in my house, I am involved in an expert system, or a series of such systems, in which I place my reliance. I have no particular fear in going upstairs in the dwelling, even though I know that in principle the structure might collapse. I know very little about the codes of knowledge used by the architect and the builder in the design and construction of the home, but I nonetheless have sfaith ' in what they have done. My sfaith is not so much in them, although I have to trust their competence, as in the authenticity of the expert knowledge which they apply« (Giddens 1990: 27f.)

Giddens' differentiation of trust in the system and faith in the internal workings of expert systems provides a valuable insight because it affords a perspective on power and knowledge that is highly relevant for the patients' perspectives of the medical system. For Giddens, the prime condition for trust is the inescapable lack of full information; accordingly all trust in expert systems is necessarily blind trust. This trust derives from faith in the reliability of principles, procedures and self-control mechanisms applied in expert systems of which the trusting person in general is ignorant.

»In conditions of modernity, attitudes of trust towards abstract systems are usually routinely incorporated into the continuity of day-to-day activities and are to a large extent enforced by the intrinsic circumstances of daily life. Thus trust is [...] a tacit acceptance of circumstances in which other alternatives are largely foreclosed.« (Giddens 1990: 90)

As our interviews and the focus group discussions make clear, while valuing science as a truth-producing expert system and a herald of progress, the nuanced opinions of our respondents have two sources. Firstly, the faith in the correctness of procedures and the application of knowledge is often challenged at the "access points « of the medical system, where our respondents interacted with concrete physicians or were >consuming health care. These are reactions to perceived malpractice or unresponsiveness on the part of physicians. But there are also effects of close encounters with science as a system of multiple, competing and even conflicting knowledges. As in the case of 
the cardiomyopathy patient, science is revealed as an exercise in generalised scepticism of its own products - and this is the second, more fundamental source of uncertainty.

\section{Experiencing / Knowing - Intersections and zones of awkward engagement}

In response to this twofold lack of confidence brought about by close encounters with the medical system, many of our respondents seek the help of patient groups. There they are looking for a special type of experiential knowledge that medical professionals - as they perceive it - are not able to provide. The statement of a male focus-group discussant from Germany, who received a heart-transplant four years ago, is an exemplary case; he describes how he hunted for information after the physicians of the Berlin Heart Center had put him on the transplant waiting list:

»the doctors are the specialists, right, but they just don't have the time to talk to you for hours on end. And above all, they haven't experienced [a heart transplantation] themselves. So there ... was this [names an association of organ transplant recipients] and I went [to one of] the regular meetings. So there I went, met the colleague [... and he] told me everything. He even came to my house to see me there. And ever since it has been much more easy for me. Enormously easy, you know. I received a lot of support there.« (focus group discussion ${ }^{8}$ )

In their analysis of the Association Française Contre les Myopathies (AMF), Vololona Rabeharisoa and Michel Callon (2004) describe two crucial functions of patient groups: they serve as devices for - as they call it - the "primitive accumulation of knowledge« and as sites for »mutual learning «: experienced patients not only give emotional support and basic information to fellow sufferers, they also accumulate knowledge, for example about individual reactions to treatments, about side-effects or firsthand data about the course of diseases. Because many of these patient-groups are devoted to rare diseases of which clinical

8 This focus group discussion was facilitated by Silke Schicktanz in Berlin (see footnote 1). 
medicine - not only because of the small patient numbers - has no sufficient knowledge, patients and their associations are likely to collect data that has the potential »to enhance the efficiency of medical services. [...] patients and their association[s] are the origin of numerous documents on the effects of drugs, and readily discuss such issues with specialists « (ibid., p. 147f), often as equals. A similar success story can be told of the German Retinitis Pigmentosa Society, founded in the late 1970s, which - like the AMF - managed to organise dispersed and fragmented research efforts in different disciplines and locations to serve their purposes. Besides collecting funds for research grants, the Society also influenced research through organising patients and making them "accessible « for researchers - by distributing questionnaires among its members or even by organised donations of tissue-samples with which to experiment (Gizycki 1987). More examples could be added, such as the impact of ACT UP, the US-American AIDS Coalition to Unleash Power, on AIDS research and treatment (Epstein 1996), or the US-American National Marfan Foundation that chose to pursue more "modest interventions « into research decisions (Heath 1997).

In front of the backdrop of these success stories, not only limited to industrialised countries, it comes as no surprise that neo-liberal health care policy makers found the figure of the expert patient to be an ideal actor: he or she accumulates valuable knowledge in support of better science, is actively involved in his or her treatment, provides support to other sufferers, and can be enrolled in enhancing the accountability of the health system through a critical evaluation of the services offered to him. ${ }^{9}$ As a recent Canadian study on citizen-participation in health care argues, this new role attributed to the expert patient also reflects a growing recognition on the part of policy makers sthat many decisions in health care involve both clinical and value choices" (Department of Health 2001). This expert patient not only reduces >value deficits (and will probably make ethicists expendable) but it is also lauded - for example - by the

9 However, there is little known about the actual functioning of many patient groups, their inner workings on a membership level etc. (Brown 1999). 
UK Department of Health as a key figure for chronic disease management in the 21st century, because his or her truly governmentalised mind-set promises better compliance and fewer expenditures for under-funded health care systems. ${ }^{10}$ It seems only a question of time until the rhetoric of the expert patient, the drafted Charters or the pilot projects will eventually materialise in more formalised participatory institutions. So is democracy progressing? Probably.

However, there are some open questions, for example: what politics of knowledge are set into motion in these initiatives? Which assumptions about the epistemic status of the knowledge accumulated by patients dominate these policy papers that try to restructure the interzone between science/medicine and the "public«? How are medicine and the patient redefined in this interzonal traffic in knowledge, care, pharmaceutical substances and the like? Whereas Vololona Rabeharisoa and Michel Callon might envision a growing interpenetration, if not integration, of knowledge practices along an epistemic continuum, British ethicist David Badcott insists on a clear demarcation line between science and the life-world and cautions against confusing experience with expertise. As he sees it, individual patients might possess considerable experience about living with their disease, but experience - to quote Badcott - is "limited to an individual [and] does not of itself give rise to generalizations that underlie reliable clinical treatment " (Badcott 2005) and research. This firm separation between science, producing reliable truths and certified expertise on the one hand and lay experience on the other indeed dominates most policy papers suggesting an increased involvement of patients into decision processes about health care delivery or research strategies. While these policies clearly react to long-standing criticisms - not seldom to those of "medicalisation « - and perceived accountability problems of medicine, these initiatives are driven by an additive model of knowledge accumulation. Science is allowed to be unchanged and objective while the patients add the »human element« - insights into suffering, what it means to

10 Along the same lines, the German Ministry of Health's initiative »Patient als Partner « envisions the enlightened patient as the ideal customer of health care provision (Mißlbeck; Ross 2005). 
manage a chronic disease on an everyday basis, how to cope with stigmatisation or how to cope with conflicting values.

I have two objections against Badcotts conceptual separation of expertise and experience, and I do not think that the additive model of knowledge "extension « that rests on this presumption helps. First objection: Badcott idealises science as producer of objective truths and he misconceptualises experience as not affording generalisations and refinement. Second objection: For Badcott and many of the authors of the mentioned policy papers, the patient is foremost an individual who experiences his disease in a radically subjective mode. The patient is rarely conceptualised as a socially embedded actor who is also involved in distributed cognitive processes, in reflection and mutual learning. For both objections I take my lead from John Dewey's concept of experience. Dewey argues that our current notion of experience was shaped by three historic episodes that defined experience in relation to reason. In classical Greek thought, experience means »the preservation, through memory, of the net result of a multiplicity of particular doings and sufferings; a preservation that affords positive skill in maintaining further practice, and promise of success in new emergencies." (Dewey 1997: 199) While there is "some knowledge of materials, methods, and aims [...] the marks of its passive, habitual origin are indelibly stamped upon it [...] it can never aspire beyond opinion." As such, experience contrasts sharply with true, universal knowledge. Experience »has to do with production « it deals with "generation, becoming, not with finality" (Dewey 1997: 200). The second historical episode that shaped notions of experience centers around the controversies between empiricist and rationalist theories of the origin and validation of scientific knowledge. Experience here comes to mean - in the words of Charles Sanders Pierce - »that which is forced upon a man's recognition will-he, nill-he, and shapes his thoughts to something quite different from what they naturally would have taken « (Peirce 1997: 150). However, mere perception does not guarantee scientific knowledge, instead, the data of perception have to undergo a qualitative transformation, namely a generalisation and idealisation. The third episode problematises experience as the outcome of "subjective sensations and ideas". Against this subjectivistic experientialism, Dewey stresses that 
any experience »always carries with it and within it certain systematised arrangements, certain classifications « (Dewey 1997:208), and »[s]ocial institutions, established political customs, effect and perpetuate modes of [...] perception that compel a certain grouping of objects, elements and values « (Dewey 1997: 209). In short, Dewey suggests something very similar to Ludwig Felck's concept of »styles of thought" (Fleck 1980): what might be termed Dewey's "styles of experience" are bound to "communities of practice« (Lave and Wenger 1991) and these socially ordered experiences afford reflective thought that transcends its experiential basis.

What is obvious is that this conception is a far cry from the above-mentioned clear-cut distinction that demarcates scientific fact from subjective experience. The objects of different styles of experience are like objects of one style of thought that are at least partially translatable into another style of thought. Of course, this would presuppose that scientific practices are conceptualised as nothing more than dependent upon a specific style of experience. The problem, then, is not so much the confusion of science and non-science, but rather that the reflective potential of everyday experience is not acknowledged. However, an even greater problem emerges when experience is used as a resource for identity politics that creates a very peculiar relationship between experience, culture, collective identity, politics, and power (Bernstein 2005). The danger that patient movements might run into is that in using "reverse affirmations « (Foucault 1981) as a political strategy to gain access to political processes, namely to use experiences of stigmatisation or exclusion based on deviant bodies, they translate experience in an unreflective, essentialist way into a means of group-formation. This essentialist trap is the dark side of the often celebrated »biosociality", for example in the form of "genetic citizenship « (Jennings 2003), a participation entitled by biological substance. In these cases, the unintended consequence of participatory politics might be that the reflective potential of experience is likely to be bypassed.

It is somewhat reassuring that many of our respondents see using their their bodies as authenticating devices for political or social action as an inevitable necessity - as a sort of walking proof. A representative example of how patients attempt to in- 
vest their experience in the context of health promotion comes from an interview conducted with a 19-year old Cypriot woman who successfully received a bone-marrow transplant:

"Since I was cured, I wanted to learn more about [the disease]. Two weeks ago there was a blood donation in school. A physician came and talked about donation and when he finished I spoke to the [300] students $[\ldots]$ and told them about my problem and urged them to donate blood because [...]. I said >I would like to talk to you. I am a living example and I needed blood many times. I never thought that I would need blood but I did. Perhaps you may need it in one month's time, you cannot know what will happen<. I think that I help with my way. I worked at the oncology department of the hospital within the context of a school working-week and I talked with many parents and they asked me many things.« (patient interview ${ }^{11}$ )

What seems evident from empirical data like those quoted above is that the changes in the relationship between citizens and their states, that must simultaneously be considered to be symptoms and results of changing governmental regimes in late modernity, have - as has been already indicated in the introduction to this volume - the unintended but often welcomed effect of making health care practices and prevention regimes a little bit more reflexive. That patients and citizens actively transform themselves from objects to subjects of health promotion, that they volunteer to take on responsibility, that they organise patient groups and are even actively involved in systematic knowledge production, that they begin to see their experience in suffering and pain as a valuable resource for others, might be seen as hopeful proof for widespread altruistic leanings and social coherence. The downside, however, is that the increasingly dismantled welfare states and their biomedical systems count on the volunteer work of their citizens "to fill the gap « between health care and health promotion on the one hand and those who need knowledge and care on the other: A new type of middle-man citizen is emerging - a knowledgeable, self-educated go-between who connects expert regimes of abstract (biomedical) knowledge with non-experts and their need

11 This interview was conducted in Nicosia by Costas Constatinou (see footnote 1). 
for substantiated, concrete know-how, in other words, what diseases mean in everyday life. Of course, it is open for debate whether these investments of experiential knowledge, provided by patients and self-trained citizen-experts, their relatives and other concerned people, are ever successfully translated into biomedical assemblages: do they ever achieve a sustained transformation of health care provision and a significant change in the attitudes, styles of thought and practices of health experts, or do they remain a welcome but marginal add-on from the perspective of biomedicine?

\section{References}

Badcott, David (2005). »The expert patient: Valid recognition or false hope « Medicine, Health Care and Philosophy 8(2): 173-178.

Beck, Stefan and Jörg Niewöhner (2006). "Somatographic investigations across levels of complexity« Journal of BioSocieties 1(2): 219-227.

Benton, Ted (2005). Biology and Social Science. Why the return of the repressed should be given a (cautious) welcome. Nature. Criticl Concepts in the Social Siences. John Bone David Inglis, Rhoda Wilkie. London and New York, Routledge. IV.

Bernstein, Mary (2005). »Identity politics« Annual Review of Sociology 31: 47-74.

Biernacki, Edmund: (2000). Zasady Poznania Lekarskiego (The principles of medical knowledge) quoted in Löwy, Ilana: Trustworthy Knowledge and Desperate Patients. Living and Working with the new medical technologies. Intersections of inquiry. Margaret Lock, Allan Young and Alberto Cambrosio. Cambridge, Cambridge University Press: 49-81.

Brown, Ian (1999). »Patient participation groups in general practice in the National Health Service« Health Expectations 3 No.3: 169-178.

Charlesworth, Simon J., Paul Gilfillan and Richard Wilkonson (2004). »Living inferiority « British Medical Bullettin 69: 49-60.

Circulaire ministérielle n 95-22 du 6 mai 1995 (1995). Charte du patient hospitalisé.

Clarke, Adele E., Janet K. Shim, Laura Mamo, Jennifer R. Fosket and Jennifer R. Fishman (2003). »Biomedicalization: Techno- 
scientific transformations of health, illness, and US biomedicine" American Sociological Review 68(2): 161-194.

Conrad, Peter (1992). »Medicalization and Social Control« Annual Review of Sociology 18: 209-232.

Department of Health (2001). The expert patient. A new approach to chronic disease management for the 21st century. London.

Dewey, John (1997). Experience and Objective Idealism. The Influence of Darwin on Philosophy and Other Essays. John Dewey. Amherst, Prometheus Books: 198-225.

Diamandouros, Nikiforos P.: (2005). »Patients' rights in Europe today. Speech by the European Ombudsman to the Second Hygeia - Harvard Medical International Conference >Preventive Medicine in the 21st Century`, Chalandri-Athens, 3 June 2005« http:/ /www.ombudsman.europa.eu/speeches/ en/2005-06-03.htm.

Dilthey, Wilhelm (1923). Einleitung in die Geisteswissenschaften: Versuch einer Grundlegung für das Studium der Gesellschaft. Leipzig, Teubner.

Epstein, Steven (1996). Impure Science. AIDS, activism, and the politics of knowledge. Los Angeles \& London, University of California Press.

Fleck, Ludwik: (1980). Entstehung und Entwicklung einer wissenschaftlichen Tatsache. Einführung in die Lehre vom Denkstil und Denkkollektiv. Mit einer Einleitung. Lothar Schäfer and Thomas Schnelle. Frankfurt/M., Suhrkamp.

Foucault, Michel (1981). The History of Sexuality, Volume 1: An Introduction. London, Pengiun.

Giddens, Anthony (1990). The Consequences of Modernity. Stanford, Stanford University Press.

Gieryn, Thomas F. (1999). Cultural Boundaries of Science. Credibility on the line. Chicago, London, University of Chicago Press.

Gizycki, Rainald von (1987). Cooperation between Medical Researchers and a Self-Help Movement: The Case of the German Retinitis Pigmentosa Society. The Social Direction of the Public Sciences. Stuart Blume et al. Dordrecht: 75-88.

Harrington, Anne (2002). Die Suche nach Ganzheit. Die Geschichte biologisch-psychologischer Ganzheitslehren: Vom Kaiserreich bis zur New-Age-Bewegung. Reinbek bei Hamburg. 
Heath, Deborah: (1997). Bodies, Antibodies, and Modest Interventions. Anthropological Interventions in Emerging Sciences and Technologies. Joseph Dumit Gary Lee Downey. Santa Fé, School of American Research Press: 67-82.

Jennings, Bruce: (2003). Genetic Citizenship. Knowledge and empowerment in personal amd civic health. Paper Prepared for The March of Dimes/Health Resources and Services Administration/ Genetic Services Branch Project on Genetic Literacy, The Hastings Center.

Lave, Jean and Etienne Wenger (1991). Situated learning: legitimate peripheral participation. Cambridge [England]; New York, Cambridge University Press.

Luhmann, Niklas: (1990). Die Wissenschaft der Gesellschaft. Frankfurt/M., Suhrkamp.

Merton, Robert (1973). Social and Cultural Contexts of Science. The Sociology of Science: Theoretical and Empirical Investigations. Robert Merton. Chicago, University Of Chicago Press.

Mißlbeck, Angela »Der Patient als Partner - wie ein Schlagwort der Reformdebatte zum Leitfaden der Praxis werden kann « Ärzte Zeitung (10.6.2005).

Mol, Annemarie (2008). The Logic of Care: Health and the Problem of Patient Choice. Abingdon, New York, Routledge.

Mol, Annemarie and John Law (2004). "Embodied Action, Enacted Bodies: the Example of Hypoglycaemia « Body Society 10(2): 43-62.

Network, Active Citizen. (2002). »European Charter of Patients Rights« http://www.patienttalk.info/european_charter.pdf ( $\mathrm{Zu}-$ gang am 10.08. 2009).

Parsons, Talcott (1951). The Social System. New York, Free Press.

Peirce, Chales S. (1997). Monist, Vol. XVI., p. 150. quoted in Dewey, John: The Influence of Darwin on Philosophy and Other Essays (1997). Amherst, Prometheus Books.

Rabeharisoa, Vololona and Michel Callon (2004). Patients and scientists in French muscular dystrophy research. States of knowledge. The coproduction of science and social order. Sheila Jasanoff. New York, Routledge: 142-160.

Ross, Melody (2005). European Charter of Patients' Rights. Protecting patients' rights across the EU. Cittadinanzattiva, Italy, Active Citizenship Network. 
Sang, Bob (2004). »Choice, participation and accountability: assessing the potential impact of legislation promoting patient and public involvement in health in the UK " Health Expectations 7(3): 187-190.

Shapin, Steven and Simon Schaffer (1985). Leviathan and the airpump: Hobbes, Boyle, and the experimental life. Princeton, Princeton University Press.

Stengers, Isabelle and David W.: Smith (2000). The Invention of Modern Science (Theory Out of Bounds). Minneapolis, University of Minnesota Press.

Strathern, Marilyn: (2000). New accountabilities. Anthropological studies in audit, ethics and the academy. Audit Cultures. Anthropological studies in accountability, ethics and the academy. Marilyn Strathern. London, Routledge: 1-18.

Sullivan, Mark (1986). »In what sense is contemporary medicine dualistic?«Culture, Medicine, and Psychiatry 10: 331-350.

Tsing, Anna Lowenhaupt (2004). Friction: An Ethnography of Global Connection. Princeton, NJ, Princeton University Press.

Weingart, Peter (2001). Die Stunde der Wahrheit? Zum Verhältnis der Wissenschaft zu Politik, Wirtschaft und Medien in der Wissensgesellschaft. Weilerswist, Velbrück Wissenschaft.

Zola, Irving K. (1983). Socio-Medical Inquiries: Recollections, Reflections and Reconsiderations. Philadelphia, Temple University Press. 